\title{
Species composition and dynamics of aphids and parasitoid wasps in maize fields in Northeastern China
}

\author{
Ying Zhang', Min-chi Zhao ${ }^{1}$, Jia Cheng ${ }^{1}$, Shuo Liu ${ }^{1}$, Hai-bin Yuan ${ }^{1}$ * \\ ${ }^{1}$ Jilin Agricultural University, Department of Plant Protection, Changchun,130118, \\ China. \\ ${ }^{*}$ Corresponding author; yhb-74@163.com
}

\section{Abstract}

Maize, Zea mays L., is the most abundant field crop in China. Aphids are the most economically damaging pest on maize, particularly in the cotton agri-ecosystems of Jilin Province, northern China. Parasitic wasps are important natural enemies of aphids, but limited information exists about their species composition, richness and seasonal dynamics in northern China. In this study, the population dynamics of maize aphids and parasitoid wasps were assessed in relation to each other during the summer seasons of two consecutive years, 2018 and 2019. We selected maize fields in the Changchun, Songyuan, Huinan and Gongzhuling areas of Jilin Province. Four species of aphids were recorded from these maize fields: Rhopalosiphum padi (L), Rhopalosiphum maidis (Fitch), Aphis gossypii Glover and Macrosiphum miscanthi (Takahashi). The dominant species in each of the four areas were R. maids (Filch) and $R$. padi in Changchun, $R$.padi in Songyuan, A. gossypii and $R$. padi in Huinan, and A.gossypii and $R$. padi in Gongzhuling. We delineated a species complex made up of primary parasitoids and hyperparasitoids associated with maize aphids. The primary parasitoids Lysiphlebus testaceipes, Binodoxys communis and Aphelinus albipodus together formed approximately $85.3 \%$ of the parasitoid complex. Pachyneuron aphidis, Phaenoglyphis villosa, Syrphophagus taeniatus and Asaphes suspensus made up the hyperparasitoids. Of the primary parasitoids, L. testaceipes was the dominant species $(81.31 \%)$. Of the hyperparasitoid group, $P$. villosa was the dominant species (68.42\%). Parasitism rates followed the fluctuation of the aphid population. The highest parasitic rate was observed during the peak period of cotton aphids. In this paper, the occurrence dynamics and dominant species of aphids and the dynamics of parasitic natural enemies of aphids in maize fields in Jilin Province are, for the first 
time, systematically reported. This study provides important information for the establishment and promotion of aphid biological control in maize fields.

\section{Introduction}

Maize is the most extensively cultivated cereal in the world and serves as a staple in many tropical, subtropical and warm temperate countries ${ }^{[1,2]}$. Maize, which originated in China, is an important crop in the northern and northeastern regions of the country, and it is predicted that, by 2050 , the demand for maize in the developing world will double ${ }^{[3]}$. The aphid is one of the most economically damaging pest on maize. The common aphid species in maize fields include $R$. padi, $R$. maidis, $M$. miscanthi and other wheat aphids. Among them, $R$. maidis and $R$. padi have the most economic effects on maize yields. The large number of aphids and the serious damage they cause lead to great losses in maize yield each year. In addition to causing direct damage by removing photoassimilates, aphids transmit several destructive maize viruses, including the maize yellow dwarf virus, barley yellow dwarf virus, sugarcane mosaic virus, and cucumber mosaic virus ${ }^{[4]}$. Damage caused to maize by aphids takes several forms, with resulting yield losses being quite variable from year to year. Growth and yield are reduced through the removal of photosynthates by large numbers of aphids ${ }^{[5]}$. For example, when the strain rate of maize reaches $25 \%$, direct or indirect losses can reach $12.5 \%{ }^{[6]}$, and the most serious losses can be up to $50 \%$, or even no maize production. Short-lived outbreaks have been reported in some areas and have at times caused considerable yield loss, which has led to various control measures ${ }^{[7,8]}$. However, control of the aphid-caused damage to maize is challenging due to aphids' high population fecundity, the difficulty of applying pesticides, and the ease with which aphids develop resistance to pesticides.

Fortunately, these aphids are attacked by a suite of natural enemies, including parasitoid wasps, which are an important component of the maize field ecosystem. Biological control services provide an effective strategy for pest suppression and natural enemy promotion. The trophic structure of natural enemies and the organization of food webs in agri-ecosystems have become key issues for biological control[9,10]. Studies have been conducted on the artificial feeding and release of predatory natural enemies of aphids in the field ${ }^{[11,12]}$. However, few have systematically studied the control effect of maize field parasitoids on maize field 
aphids. Lack of a comprehensive understanding of the parasitoid community in maize fields and of the efficiency of parasitoids in controlling these pests, prevails.

Aphid-primary parasitoid relationships have been extensively documented, but aphids and primary parasitoid populations can also be influenced by hyperparasitoids, of which reports are mostly lacking. For example, on alfalfa crops in Spain, 13 Aphidiinae parasitoid species and four species of aphelinids, as well as eight hyperparasitoids were recorded ${ }^{[13]}$. Cereal aphids are subject to parasitism rates of 30 $80 \%$ on Danish and New Zealand winter wheat, mostly from Aphidius ervi Haliday and Aphidius rhopalosiphi (De Stefani-Perez ${ }^{[14]}$. In northern China, two primary parasitoid species and ten different hyperparasitoid species were collected in cotton fields ${ }^{[15]}$. In another study, three primary parasitoid species were found, and the hyperparasitoid guild was more diverse, consisting of 14 species ${ }^{[15,16]}$. Two primary parasitoid species and 4 secondary parasitoids were found on corn leaves, consisting of the species Aphelinus nigritus (Howard), A. varipes (Forester), Pachyneuron siphonophorae (Ashmead), Aphidencyrtus aphidivorus (Mayr), Charips sp., and Asaphes hicens (Provancher) ${ }^{[17]}$. However, research on parasitoids in maize fields is still scarce.

Here, we investigated the parasitoid species composition and the population dynamics of maize aphids and their parasitoids in 3 maize fields in 2018 and 2019 in northern China. This work will support future research on the species characterization and community composition of maize aphid parasitoids in China.

\section{Materials and Methods}

\section{Location}

The experimental fields were maize fields located at the Changchun(E125.35 ${ }^{\circ}, \mathrm{N}$

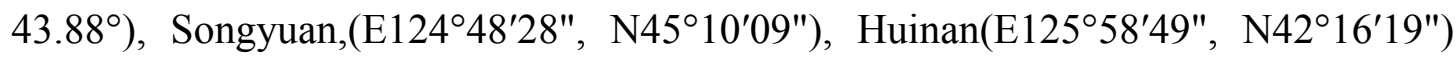
and Gongzhuling(E125 58'49", N42 $\left.{ }^{\circ} 16^{\prime} 19^{\prime \prime}\right)$ research station in Jilin Province, China. The fields were cultivated according to the management practices of local farmers, with no crop rotation. No pesticides were applied during the growing season.

\section{Field Survey}

Sampling started in early July when winged aphids migrated on maize plants and was performed three times per month per site until maize harvest. A five-point sampling method was used to set up three groups of sample repeats in each area, each 
of which was repeated at five points, and 20 maize plants were randomly selected at each point. The populations of aphids and mummified aphids were recorded separately.

\section{Data analysis}

Parasitism rates were calculated by dividing the number of aphid mummies by the sum of mummified and living aphids. The field data obtained were preliminarily sorted in Excel and analyzed by SPSS 17.0.

\section{Aphid Advantage Analysis Method}

Data were analyzed using Berger Parker's dominance ${ }^{[18]}$ and Simpson's dominant concentration ${ }^{[19]}$ methods, using this formula,

$$
\mathrm{B}=\mathrm{n}_{\max } / \mathrm{N}, \mathrm{C}=\sum\left(\mathrm{n}_{\mathrm{i}} / \mathrm{N}\right)^{2}
$$

Where $\mathrm{B}$ is aphid population dominance, $\mathrm{C}$ is the aphid community dominance concentration index, $\mathrm{n}_{\max }$ is the number of aphid species in the aphid community, $\mathrm{N}$ is the total number of organisms in the community, and $\mathrm{n}_{\mathrm{i}}$ is the number of individuals of the first species. The greater the population dominance is, the greater the individual difference between species in the community, the prominent the dominant species, the fiercer the competition among species, and the greater unstable state of the community. The dominant concentration index is the concentration trend of the number of individuals in the reaction species.

\section{Results}

\section{Identification of aphid species in maize fields in Jilin province}

Four different aphids species were identified under a microscope: $R$. padi (Fig 1A), R. maids(Fig 1B), A. gossypii (Fig 1C), and M. miscanthi (Fig 1D). For a long time in China, the aphid M. miscanthi had been misidentified as Macrosiphum avenae (Fabricius). However, Guangxue (1999) showed that the distribution of M. avenae was only limited to some areas in Yili, Xinjiang, China. Thus M. miscanthi is the correct identification for those identified as M. avenae in China in the past ${ }^{[20]}$.

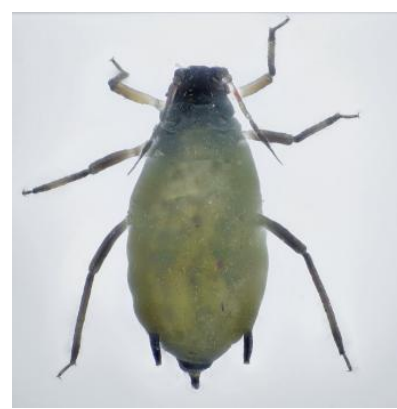

A

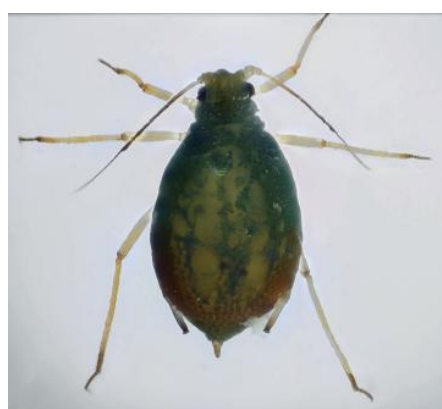

B 


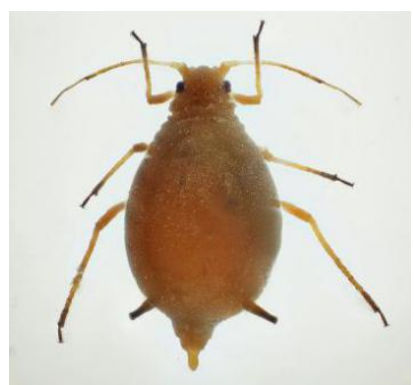

C

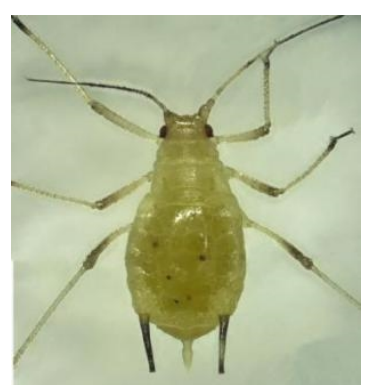

$\mathrm{D}$

Fig 1. Morphology or 4 malze neld aphids under uitraclear microscopy: (A) $R$. padi; (B) R. maids; (C) A. gossypii; (D) M. miscanthi.

\section{Dominant aphid species and population dynamics of maize fields in Changchun}

Different aphid species caused damage to maize at different times in the Changchun area. The dominant aphid species were also different in different periods. In early July 2018-2019, the presence of $R$. padi, A. gossypii and M. miscanthi were recorded, of which the dominant species was $R$. padi. The highest population dominance, B, was 0.87 , and the advantage concentration index, C, was 0.77 . However, the presence of $R$. maids was recorded in early August, and by the end of August to early September, its population had become the largest. Thus, the dominant aphid species in the maize field gradually changed from $R$. padi to $R$. maids. The population dominance $\mathrm{B}$ gradually rose from 0.49 to 0.91 , and the advantage concentration index $\mathrm{C}$ increased from 0.46 to 0.84 . (Table 1)

Table 1. The population dynamics and dominance of aphids in Changchun area maize.

\begin{tabular}{c|c|c|c|c|c|c|c|c|c|c|c}
\hline Date & $\begin{array}{c}\text { R.maid } \\
\boldsymbol{s}\end{array}$ & $\begin{array}{c}\text { Percentage } \\
(\%)\end{array}$ & $\boldsymbol{R}$.padi & $\begin{array}{c}\text { Percentag } \\
\text { e (\%) }\end{array}$ & A. gossypii & $\begin{array}{c}\text { Percentage } \\
(\%)\end{array}$ & M. miscanthi & $\begin{array}{c}\text { Percentage } \\
(\%)\end{array}$ & B & C \\
\hline E18 & Early Jul & 0.00 & $0.00 \%$ & 333.33 & $63.69 \%$ & 190.00 & $36.31 \%$ & 0.00 & $0.00 \%$ & 0.64 & 0.54 \\
\hline Mid-Jul & 0.00 & $0.00 \%$ & 334.67 & $46.55 \%$ & 384.33 & $53.45 \%$ & 0.00 & $0.00 \%$ & 0.53 & 0.50 \\
\hline Late Jul & 0.00 & $0.00 \%$ & 369.33 & $65.91 \%$ & 188.00 & $33.55 \%$ & 3.00 & $0.54 \%$ & 0.66 & 0.55 \\
\hline Early Aug & 5.00 & $0.70 \%$ & 544.00 & $75.66 \%$ & 155.00 & $21.56 \%$ & 15.00 & $2.09 \%$ & 0.76 & 0.62 \\
\hline
\end{tabular}




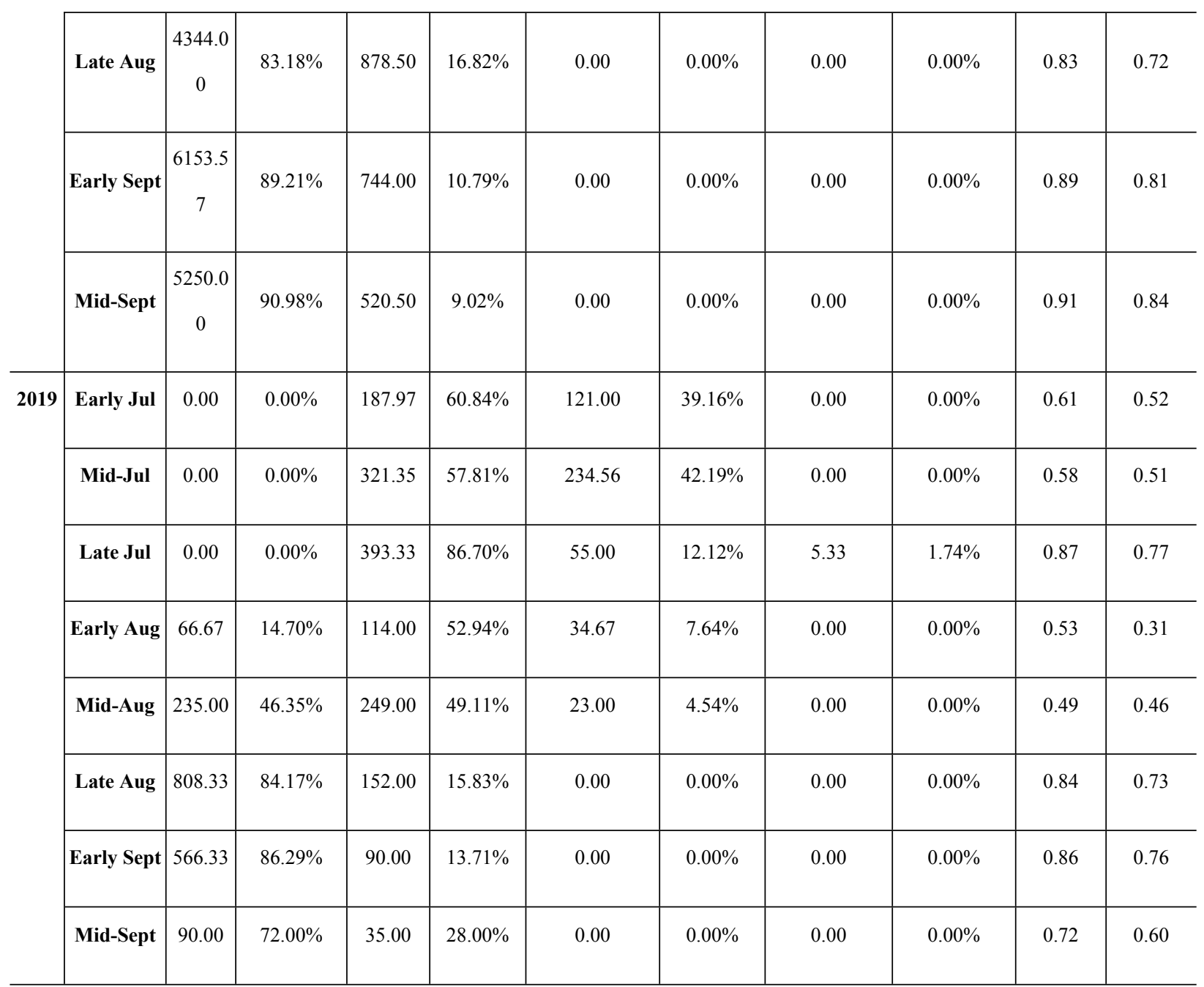

\section{Dominance and population dynamics of aphid species in maize fields in Songyuan.}

The presence of $R$. padi, A. gossypii Glover and M. miscanthi were recorded in early July, 2018 and 2019. The presence of R. maids was recorded in early August. From July to September, the dominant species was $R$. padi. The highest population dominance $\mathrm{B}$ was 0.99 , and the advantage concentration index $\mathrm{C}$ was 1 . In mid-August and late August, the population of $R$. padi reached a maximum. The aphid density per 100 plants was greater than 30,000 in 2018, and in 2019 , the number of aphids per 100 plants reached more than 15,000. In the whole maize growth period, a small number of $R$. maids and M.miscanthi were recorded. (Table 2)

Table2. The population dynamics and dominance of aphids in Songyuan area maize field in 2018 and 2019 
bioRxiv preprint doi: https://doi.org/10.1101/2020.10.19.345215; this version posted October $19,2020$. The copyright holder for this preprint (which was not certified by peer review) is the author/funder, who has granted bioRxiv a license to display the preprint in perpetuity. It is made available under aCC-BY 4.0 International license.

\begin{tabular}{|c|c|c|c|c|c|c|c|c|c|c|c|}
\hline & Date & R. maids & $\begin{array}{c}\text { Percentage } \\
(\%)\end{array}$ & R. padi & $\begin{array}{c}\text { Percentage } \\
(\%)\end{array}$ & A. gossypii & $\begin{array}{c}\text { Percentage } \\
(\%)\end{array}$ & $\begin{array}{c}M . \\
\text { miscanthi }\end{array}$ & $\begin{array}{c}\text { Percentage } \\
(\%)\end{array}$ & B & C \\
\hline \multirow[t]{8}{*}{2018} & Early Jul & 0.00 & $0.00 \%$ & 31.67 & $72.52 \%$ & 12.00 & $27.48 \%$ & 0.00 & $0.00 \%$ & 0.73 & 0.60 \\
\hline & Mid-Jul & 0.00 & $0.00 \%$ & 45.89 & $43.32 \%$ & 34.60 & $32.66 \%$ & 25.45 & $24.02 \%$ & 0.43 & 0.35 \\
\hline & Late Jul & 0.00 & $0.00 \%$ & 63.00 & $65.78 \%$ & 0.00 & $0.00 \%$ & 32.78 & $34.22 \%$ & 0.66 & 0.55 \\
\hline & Early Aug & 36.00 & $6.59 \%$ & 502.00 & $91.86 \%$ & 0.00 & $0.00 \%$ & 8.50 & $1.56 \%$ & 0.92 & 0.85 \\
\hline & Mid-Aug & 96.00 & $3.08 \%$ & 3005.83 & $96.53 \%$ & 12.00 & $0.39 \%$ & 0.00 & $0.00 \%$ & 0.97 & 0.93 \\
\hline & Late Aug & 41.00 & $0.11 \%$ & $\begin{array}{c}38857.1 \\
0\end{array}$ & $99.89 \%$ & 0.00 & $0.00 \%$ & 0.00 & $0.00 \%$ & 0.99 & 1.00 \\
\hline & Early Sept & 165.00 & $45.21 \%$ & 175.00 & $47.95 \%$ & 25.00 & $6.85 \%$ & 0.00 & $0.00 \%$ & 0.48 & 0.44 \\
\hline & Mid-Sept & 75.00 & $88.24 \%$ & 10.00 & $11.76 \%$ & 0.00 & $0.00 \%$ & 0.00 & $0.00 \%$ & 0.88 & 0.79 \\
\hline \multirow[t]{8}{*}{2019} & Early Jul & 0.00 & $0.00 \%$ & 61.67 & $69.42 \%$ & 26.67 & $30.02 \%$ & 0.50 & $0.56 \%$ & 0.69 & 0.57 \\
\hline & Mid-Jul & 0.00 & $0.00 \%$ & 89.78 & $49.48 \%$ & 57.89 & $31.90 \%$ & 33.78 & $18.62 \%$ & 0.49 & 0.38 \\
\hline & Late Jul & 0.00 & $0.00 \%$ & 170.00 & $81.77 \%$ & 0.00 & $0.00 \%$ & 37.89 & $18.23 \%$ & 0.82 & 0.70 \\
\hline & Early Aug & 56.67 & $14.40 \%$ & 308.33 & $78.34 \%$ & 15.00 & $3.81 \%$ & 13.56 & $3.45 \%$ & 0.78 & 0.64 \\
\hline & Mid-Aug & 43.00 & $0.27 \%$ & $\begin{array}{c}16166.0 \\
0\end{array}$ & $99.73 \%$ & 0.00 & $0.00 \%$ & 0.00 & $0.00 \%$ & 0.99 & 0.99 \\
\hline & Late Aug & 0.00 & $0.00 \%$ & 270.00 & $94.74 \%$ & 15.00 & $5.26 \%$ & 0.00 & $0.00 \%$ & 0.95 & 0.90 \\
\hline & Early Sept & 0.00 & $0.00 \%$ & 96.83 & $66.86 \%$ & 48.00 & $33.14 \%$ & 0.00 & $0.00 \%$ & 0.67 & 0.56 \\
\hline & Mid-Sept & 0.00 & $0.00 \%$ & 74.00 & $18.55 \%$ & 325.00 & $81.45 \%$ & 0.00 & $0.00 \%$ & 0.81 & 0.70 \\
\hline
\end{tabular}




\section{Dominances and population dynamics of aphid species in maize fields in Huinan}

The presence of $R$. padi and A. gossypii were recorded in early July 2018 and 2019 and that of R.maids (Filch) was recorded in late August. In July, the dominant species was $A$. gossypii. The highest population dominance B was 0.77 , and the advantage concentration index $\mathrm{C}$ was 0.65 . $R$. padi became the dominant species in early August to mid-September. The highest population dominance B was 0.95 and the advantage concentration index $\mathrm{C}$ was 0.91 . The population of $R$. padi reached a maximum in early September. The aphid density per 100 plants was 9326.25 in 2018. In 2019, the number of aphids per 100 plants reached 4538.89. In the whole maize growth period, a small number of $M$. miscanthi were recorded (Table 3).

Table3. The population dynamics and dominance of aphids in the Huinan area maize field in 2018 and 2019.

\begin{tabular}{|c|c|c|c|c|c|c|c|c|c|c|c|}
\hline & Date & R.maids & $\begin{array}{c}\text { Percentage } \\
(\%)\end{array}$ & R.padi & $\begin{array}{c}\text { Percentage } \\
(\%)\end{array}$ & A. gossypii & $\begin{array}{c}\text { Percentage } \\
(\%)\end{array}$ & $\begin{array}{c}\text { M. } \\
\text { miscanthi }\end{array}$ & $\begin{array}{c}\text { Percentage } \\
(\%)\end{array}$ & B & $\mathbf{C}$ \\
\hline \multirow[t]{8}{*}{2018} & Early Jul & 0.00 & $0.00 \%$ & 48.89 & $28.83 \%$ & 120.67 & $71.17 \%$ & 0.00 & $0.00 \%$ & 0.71 & 0.59 \\
\hline & Mid-Jul & 0.00 & $0.00 \%$ & 101.25 & $39.27 \%$ & 156. 34 & $60.63 \%$ & 0.25 & $0.10 \%$ & 0.61 & 0.52 \\
\hline & Late Jul & 0.00 & $0.00 \%$ & 68.00 & $54.54 \%$ & 56.67 & $45.46 \%$ & 0.00 & $0.00 \%$ & 0.55 & 0.50 \\
\hline & Early Aug & 0.00 & $0.00 \%$ & 72.00 & $74.40 \%$ & 24.78 & $25.60 \%$ & 0.00 & $0.00 \%$ & 0.74 & 0.62 \\
\hline & Mid-Aug & 0.00 & $0.00 \%$ & 325.65 & $89.88 \%$ & 36.68 & $10.12 \%$ & 0.00 & $0.00 \%$ & 0.90 & 0.82 \\
\hline & Late Aug & 222 & $29.30 \%$ & 507. 86 & $67.02 \%$ & 26.78 & 3. $53 \%$ & 1.11 & $0.15 \%$ & 0.67 & 0.45 \\
\hline & Early Sept & 2451 & $20.69 \%$ & 9326. 25 & $78.73 \%$ & 68.78 & $0.58 \%$ & 0.00 & $0.00 \%$ & 0.79 & 0.62 \\
\hline & Mid-Sept & 913.33 & $33.51 \%$ & 1809.50 & $66.39 \%$ & 2.87 & $0.11 \%$ & 0.00 & $0.00 \%$ & 0.66 & 0.44 \\
\hline \multirow[t]{3}{*}{2019} & Early Jul & 0.00 & $0.00 \%$ & 78.75 & $22.52 \%$ & 270.67 & 77. $39 \%$ & 0.33 & $0.10 \%$ & 0.77 & 0.65 \\
\hline & Mid-Jul & 0.00 & $0.00 \%$ & 211.83 & $41.74 \%$ & 295.67 & $58.26 \%$ & 0.00 & $0.00 \%$ & 0.58 & 0.51 \\
\hline & Late Jul & 0.00 & $0.00 \%$ & 268.63 & $36.11 \%$ & 475.25 & $63.89 \%$ & 0.00 & $0.00 \%$ & 0.64 & 0.54 \\
\hline
\end{tabular}




\begin{tabular}{|l|l|l|l|l|l|l|l|l|l|l}
\hline Early Aug & 0.00 & $0.00 \%$ & 916.44 & $73.93 \%$ & 323.22 & $26.07 \%$ & 0.00 & $0.00 \%$ & 0.74 & 0.61 \\
\hline Mid-Aug & 0.00 & $0.00 \%$ & 1467.25 & $83.60 \%$ & 286.45 & $16.32 \%$ & 1.33 & $0.08 \%$ & 0.84 & 0.73 \\
\hline Late Aug & 14.38 & $0.7 \%$ & 1922.88 & $94.25 \%$ & 100.63 & $4.93 \%$ & 2.38 & $0.12 \%$ & 0.94 & 0.89 \\
\hline Early Sept & 108.78 & $2.28 \%$ & 4538.89 & $95.13 \%$ & 123.67 & $2.59 \%$ & 0.00 & $0.00 \%$ & 0.95 & 0.91 \\
\hline Mid-Sept & 469.33 & $27.14 \%$ & 1236.67 & $71.51 \%$ & 23.46 & $1.36 \%$ & 0.00 & $0.00 \%$ & 0.72 & 0.51 \\
\hline
\end{tabular}

\section{Dominance and population dynamics of aphid species in}

\section{maize fields in Gongzhuling.}

The presence of R. padi, A. gossypii and M. miscanthi were recorded in the first ten days of July 2018 and 2019. The presence of $R$. maids was recorded in August. A. gossypii became the dominant species in July-August. Its population dominance $\mathrm{B}$ was 1 , and the advantage concentration index $\mathrm{C}$ was 1 . The dominant aphid species in the maize field gradually changed from A. gossypii to R.padi from August to September, and the population dominance B of the latter rose from 0.70 to 0.99 . The advantage concentration index $\mathrm{C}$ rose from 0.57 to 0.99 while the population increased. The aphids $R$. maids and M. miscanthi were present in small numbers (Table 4).

Table 4. The population dynamics and dominance of aphids in Gongzhuling area maize field in 2018 and 2019

\begin{tabular}{c|c|c|c|c|c|c|c|c|c|c|c}
\hline Date & $\begin{array}{c}\text { R. } \\
\text { maids }\end{array}$ & $\begin{array}{c}\text { Percentage } \\
(\%)\end{array}$ & R. padi & $\begin{array}{c}\text { Percentage } \\
(\%)\end{array}$ & A. gossypii & $\begin{array}{c}\text { Percentage } \\
(\%)\end{array}$ & M. & $\begin{array}{c}\text { Percentage } \\
\text { miscanthi }\end{array}$ & B & C \\
\hline Early Jul & 0 & $0 \%$ & 8.33 & $2.19 \%$ & 371.67 & $97.76 \%$ & 0.17 & $0.04 \%$ & 0.98 & 0.96 \\
\hline Mid-Jul & 0 & $0 \%$ & 83.33 & $9.69 \%$ & 768.56 & $89.39 \%$ & 7.89 & $1 \%$ & 0.89 & 0.81 \\
\hline Late Jul & 0 & $0 \%$ & 439.89 & $38.58 \%$ & 666.44 & $58.45 \%$ & 33.78 & $2.96 \%$ & 0.58 & 0.49 \\
\hline Early Aug & 35 & $2.32 \%$ & 647.11 & $42.94 \%$ & 847.88 & $56.26 \%$ & 12 & $0.79 \%$ & 0.56 & 0.50 \\
\hline Mid-Aug & 47.5 & $1.730 \%$ & 678.55 & $24.70 \%$ & 2067.33 & $75.26 \%$ & 1.09 & $0 \%$ & 0.75 & 0.63 \\
\hline Late Aug & 25.37 & $0.92 \%$ & 1316 & $69.81 \%$ & 543.67 & $29 \%$ & 0 & $0 \%$ & 0.70 & 0.57 \\
\hline
\end{tabular}




\begin{tabular}{|c|c|c|c|c|c|c|c|c|c|c|c|}
\hline & Early Sept & 31.5 & $1.46 \%$ & 1897.5 & $87.68 \%$ & 235 & $11 \%$ & 0 & $0 \%$ & 0.88 & 0.78 \\
\hline & Mid-Sept & 5.97 & $0.27 \%$ & 2104.34 & $93.89 \%$ & 131 & $6 \%$ & 0 & $0 \%$ & 0.94 & 0.88 \\
\hline \multirow[t]{8}{*}{2019} & Early Jul & 0 & $0 \%$ & 0 & $0.00 \%$ & 22.67 & $100.00 \%$ & 0 & $0 \%$ & 1 & 1.00 \\
\hline & Mid-Jul & 0 & $0.00 \%$ & 6.33 & $1.89 \%$ & 264 & $78.73 \%$ & 65 & $19.38 \%$ & 0.79 & 0.66 \\
\hline & Late Jul & 0 & $0.00 \%$ & 0 & $0.00 \%$ & 461.33 & $93.89 \%$ & 30 & $6.11 \%$ & 0.94 & 0.89 \\
\hline & Early Aug & 15 & $0.45 \%$ & 591.67 & $17.91 \%$ & 2696.67 & $81.63 \%$ & 0 & $0.00 \%$ & 0.82 & 0.70 \\
\hline & Mid-Aug & 5 & $0.07 \%$ & 612.33 & $8.04 \%$ & 7002.33 & $91.90 \%$ & 0 & $0.00 \%$ & 0.92 & 0.85 \\
\hline & Late Aug & 0 & $0.00 \%$ & 1224 & $33.50 \%$ & 2430 & $66.50 \%$ & 0 & $0.00 \%$ & 0.67 & 0.55 \\
\hline & Early Sept & 27 & $1.16 \%$ & 2235 & $96.29 \%$ & 56 & $2.41 \%$ & 3 & $0.13 \%$ & 0.96 & 0.93 \\
\hline & Mid-Sept & 0 & $0.00 \%$ & 2530 & $99.49 \%$ & 13 & $0.51 \%$ & 0 & $0.00 \%$ & 0.99 & 0.99 \\
\hline
\end{tabular}

\section{Species composition of parasitic wasps}

In 2019, a total of 1,448 parasitoid specimens were collected including three primary parasitoid species: B. communis, L. testaceipes and A. albipodus; and four different hyperparasitoid species: P. aphidis, P. villosa, S. taeniatus and A. suspensus (Fig. 2). They passed molecular and morphological identifications. The proportion of primary parasitoids was $85.3 \%$, and the proportion of hyperparasitoid species was $14.7 \%$. L .testaceipes was the dominant primary parasitoid formed $(81.31 \%)$ while P.villosa was the dominant hyperparasitoid (68.42\%) (Fig 3). The parasitic rate increased with increase in aphid occurrence and vice versa. At the peak of aphid occurrence in mid-August, a higher parasitic rate of $1.79 \%$ was recorded for the parasitoids. Thereafter, the parasitic rate decreased to 0 by mid-September (Fig 4).
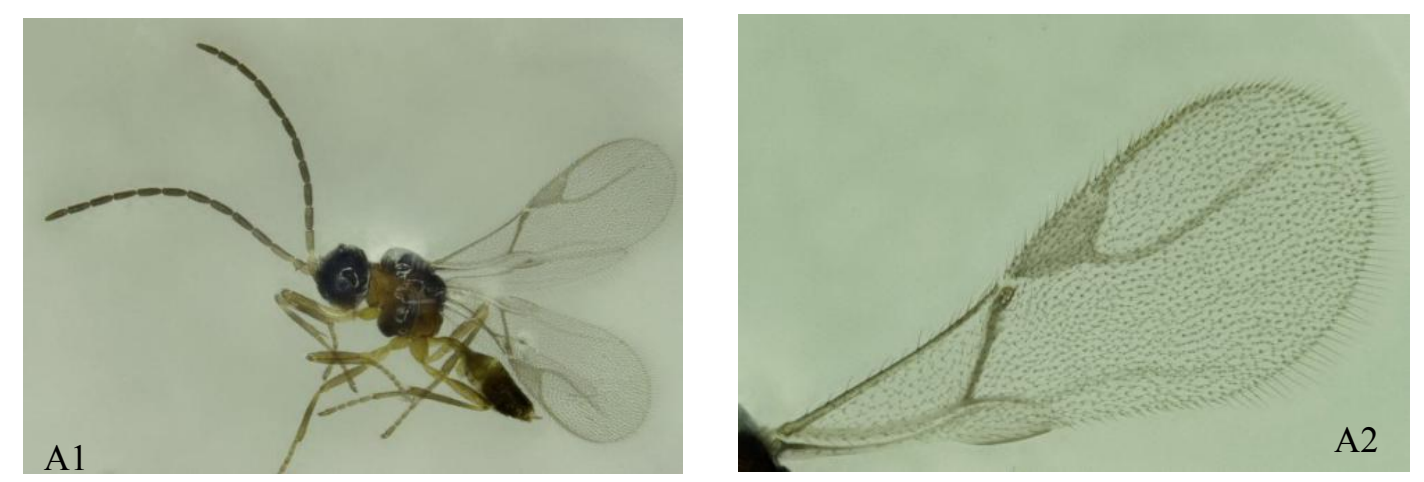
bioRxiv preprint doi: https://doi.org/10.1101/2020.10.19.345215; this version posted October 19, 2020. The copyright holder for this preprint (which was not certified by peer review) is the author/funder, who has granted bioRxiv a license to display the preprint in perpetuity. It is made available under aCC-BY 4.0 International license.
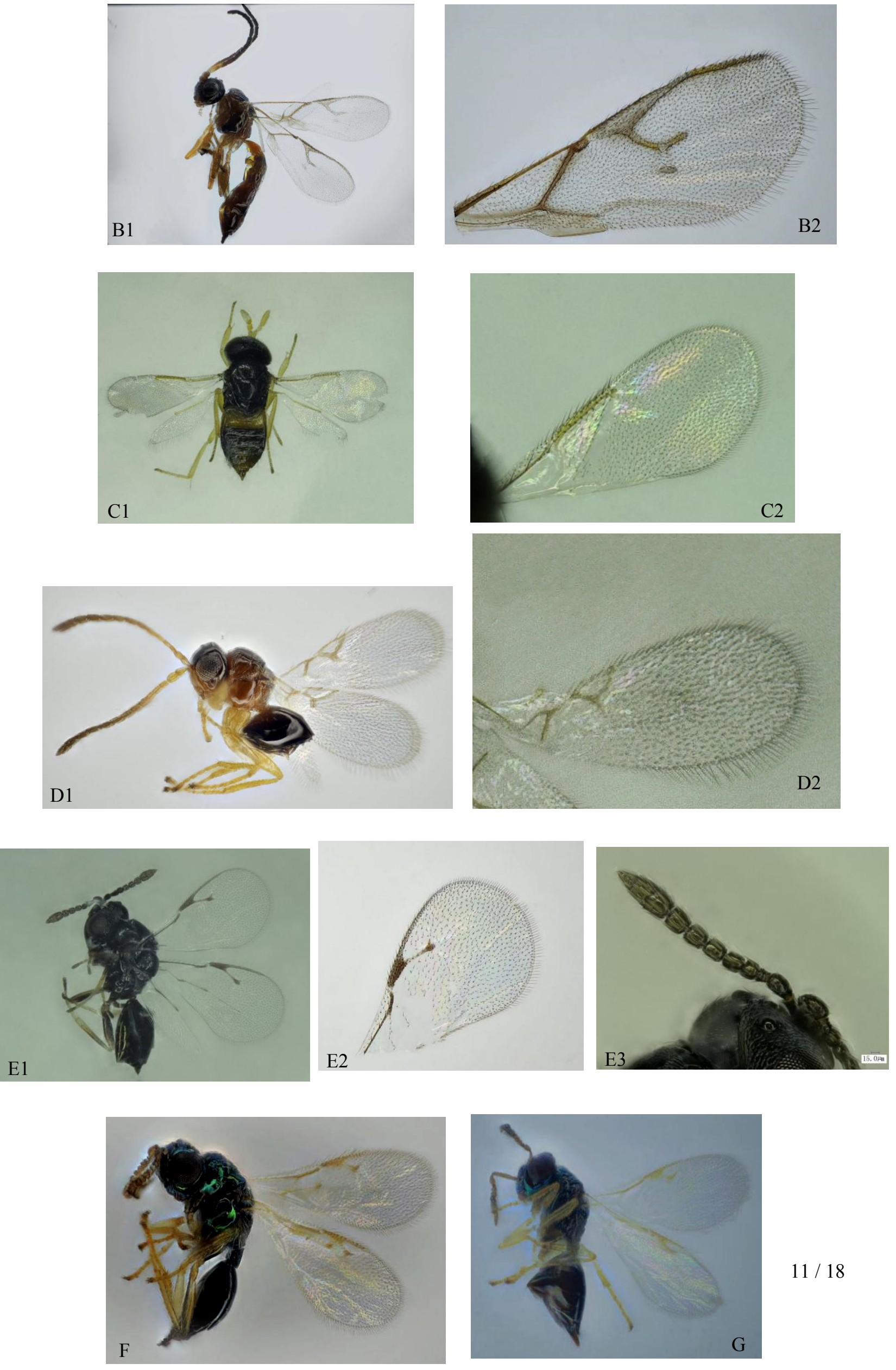
Fig 2. Morphology of 7 parasitic wasps under an Ultraclear Microscope. (A1, A2)

B. communis; (B1, B2) L. testaceipes; (C1, C2) A. albipodus; (D1, D2) P. aphidis;

(E1, E2, E3) P. villosa; (F) S. taeniatus; (G) A. suspensus.

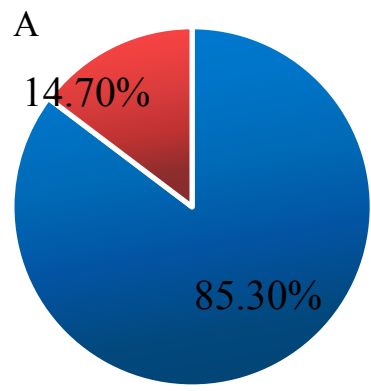

- primary parasitoid = hyperparasitoid

B

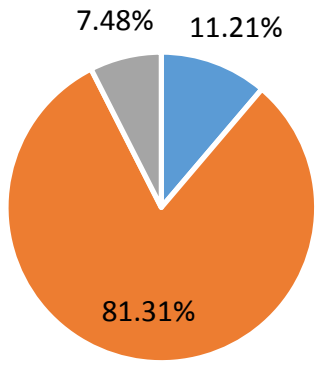

- Binodoxys communis

- Aphelimus albipodus
- Lysiphlebus testaceipes

- Pachyneuron aphidis $\quad$ - Phaenoglyphis villos

- Syrphophagus taeniatus $\quad$ - Asaphes suspensus.

Fig3. Composition of the parasitoids associated with aphids in maize fields in

Jilin Province in 2019. (A) Composition of the parasitoids. (B) Composition of the primary parasitoids. (C) Composition of the hyperparasitoids. 


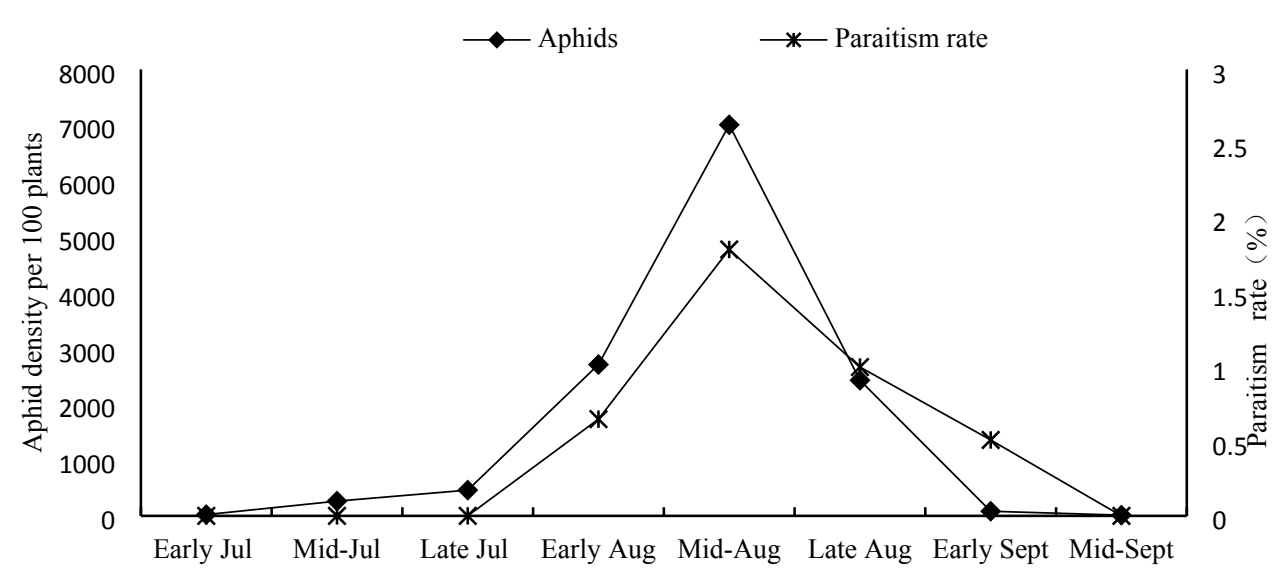

Fig 4. Maize field aphids density and parasitism dynamics

\section{Discussion}

Since the 1950s, aphids have been considered as the main pests affecting maize in many countries and therefore systematic and comprehensive research on their biological characteristics, the relationship between their reproduction and their hosts, their species composition, and the influence of the environment on their reproduction have been carried out ${ }^{[6,21]}$. However, compared to that in other countries, research on aphids in China started later. In recent years, aphids have caused serious damage to maize in some fields in China, which seriously endangers maize production. The study of aphids' occurrence and the cause of their outbreaks have attracted the attention of many agricultural researchers ${ }^{[22]}$. We investigated the occurrence dynamics and species composition of aphids and parasitoids in three maize-growing areas in Jilin Province over two years. This study revealed that 4 species of aphids occurred in the maize fields in this province: R. padi, R. maidis, A. gossypii and $M$. miscanthi. A. gossypii was found on the back of the lower leaves of maize plants, and R. maidis occurred first in the lower part of the maize and the lower leaf, and the gradually transferred upward to the female ear of maize when it aged. $R$. padi was found in the male and female ear bract leaves, and M. miscanthi on the lower stem of the maize plant. This result is consistent with the results of other research conducted in China. Yang et al. (2013) reported that the species of maize aphids found in Jilin Province were $R$. maids and $R$. padi ${ }^{[23]}$. In Haerbin province, the aphid species reported as found in maize fields were $R$. maids, $R$. padi, A. gossypii, M. miscanthi 
and Schizaphis graminum (Rondani) ${ }^{[22,24,25]}$. However, these reports differ with the results from studies conducted in maize fields in other countries. For instance, $R$. padi (L.), Sitobion avenae (F.) and Metopolophium dirhodum (Walker) were the most abundant aphid species attacking maize in the northeastern Iberian Peninsula ${ }^{[26]}$. Thirteen species, including Aphis craccivora Koch, Aphis fabae Scopoli, A. gossypii, Aphis maidiradicis Forbes, Hysteroneura setariae (Thomas), Macrosiphum euphorbiae (Thomas), Metopolophium dirhodium (Walker), Myzus persicae (Sulzer), R.maidis, R.padi, Sipha flava (Forbes), Schizaphis graminum (Rondani), and Sitobion avenae (Fabricius) were associated with maize in the United States ${ }^{[27]}$. R.maidis and R.padi were reported as the two predominant aphid species on maize in the United States,Iowa ${ }^{[28,29]}$. However, we found that the dominant aphid species was different in each of the three maize fields. The dominant species in the Gongzhuling maize field was the cotton aphid, which was the first time that this species has been reported in this area. The difference in aphid species occurrence may be related to the regional differences in temperature and surrounding crops.

The distribution of parasitic wasps is almost nationwide, distributed in northern China, namely in the Jilin, Hebei, Shaanxi and Henan Provinces ${ }^{[30]}$. Parasitoids have been broadly studied in China ${ }^{[31]}$. However, there is little research and few reports on parasitoids in maize fields. Archer (1972) only collected parasitic wasps from $R$. maids but did not conduct any research on maize fields. Our study reports on the parasitiods found in maize fields: of the four maize fields chosen, most parasitoids occurred in the Gongzhuling area, while fewer parasitoids occurred in other areas. Analysis of the parasitoid species composition was therefore limited to Gongzhuling. The three primary parasitoid species included L. testaceipes, B. communis, and $A$. albipodus. There were four different hyperparasitoid species, P. aphidis, P. villosa, $S$. taeniatus and Asaphes suspensus. Most of these parasitoids were found on A. gossypii and M.miscanthi. In many respects, the L. testaceipes establishment in southern France and other areas of the Mediterranean region may be considered a useful model for biological control and integrated pest management ${ }^{[32]}$. The results showed that the aphid species, $R$. maidis could be used as an alternative host for the reproduction of the parasitoid L. testaceipes on sorghum ${ }^{[33]}$. In northern China, three primary parasitoid species and 12 hyperparasitoids on A. gossypii were recorded in cotton fields ${ }^{[15]}$, while three parasitoids and 15 hyperparasitoids were collected in wheat fields ${ }^{[32]}$. 
Maize aphid population densities were low during this study earlier on and peaked midway through the maize growing period. Parasitism rates increased throughout nearly the entire maize growing season and followed the trends in growth and decline of the aphid populations, a typical seasonal dynamic of aphid-parasitoid interactions ${ }^{[34]}$. However, the highest parasitic rate was only $1.79 \%$ in the whole maize growth cycle, which indicated that the field parasitoids may not effectively control the occurrence of aphids. Our next focus is to conduct laboratory studies on the parasitic function to clarify the reasons for the low parasitic rate recorded in the field and to continue to improve understanding of the parasitic bee species in the maize field.

\section{Conclusions}

Our results showed that aphid species in maize fields in Jilin Province included R. padi, R. maidis, A. gossypii and M. miscanthi. Also, species dominance and occurrence dynamics of aphids in maize fields were different between the different maize fields. Three primary parasitic wasps and five secondary parasitic wasps were recorded in addition. The primary parasitoids $(85.3 \%)$ included L. testaceipes, $B$. communis and $A$. albipodus. The hyperparasitoids (14.7\%) were P. aphidis, P. villosa, S. taeniatus and A. suspensus. L. testaceipes was the dominant primary parasitoid species (81.31\%) while P.villosa was the dominant hyperparasitoid species (68.42\%). The parasitic rate increased with increasing aphid occurrence and vice versa. The highest parasitic rate $(1.79 \%)$ was recorded at the peak of aphid occurrence in mid-August.

\section{Acknowledgments}

We are much thankful to our partners for their support of sample collection, insect rearing and laboratory assays.This research was funded by the The National Science and Technology major project of China (Grant No.2019ZX08012004-009), and the National Key Research and Development Program of China (Grant No.2017YFD0300606) We also appreciate the College of Plant Protection, Jilin Agricultural University, providing test facilities.

\section{Author Contributions}

Conceptualization, Ying Zhang and Hai-bin Yuan; Investigation, Ying Zhang, Min-chi Zhao and Jia Cheng; Data curation,Shuo Liu; Writing-Original Draft Preparation, Ying Zhang; 


\section{References}

1. Onwueme IC, Sinha TD. Field crop production in tropical Africa. 1991;20 : 267-273

2. Watson RT, Noble IR, Bolin B, Ravindranath NH, Verardo DJ, Dokken DJ, et al. Land Use, Land-Use Change, and Forestry. A Special Report of the Ipcc. 2000(4):375.

3. Zhu T, Ringler C, Rosegrant MW. Viewing Agricultural Water Management Through a Systems Analysis Lens. Water Resources Research. 2019;55:28-30.

4. El-Muadhidi MA, Makkouk KM, Kumari SG, Jerjess M, Tarik F. Survey for legume and cereal viruses in Iraq. Phytopathologia Mediterranea. 2001;40(3):224-33.

5. Bing JW, Guthrie WD, Dicke FF, Obrycki JJ. Seedling Stage Feeding by Corn Leaf Aphid (Homoptera: Aphididae): Influence on Plant Development in Maize. Journal of Economic Entomology. 1991(2):625-32.

6. Judenko E. Analytical method for assessing yield losses caused by pests on cereal crops with and without pesticides. 1973.

7. Shen Hongli. Lu Jiangao. Analysis on the occurrence and control of corn aphid.Tianjin Agriculture and Forestry Science and Technology 2003;6:10-11.

8. Ding Wei. Zhao Zhimo. Wang Jinjun. Chen Guihong. Analysis of the Niche of Three Corn Aphid Populations. Chinese Journal of Applied Ecology 2003;14:1481-1484.

9. Kamenova, Stefaniya, Mayer, Rebecca, Rubbmark, Oskar, et al. Comparing three types of dietary samples for prey DNA decay in an insect generalist predator. Molecular Ecology Resources. 2018;7:343-345.

10. Dardan, Klimenta, Bojan, Perović, Jelena, Klimenta, et al. Controlling the thermal environment of underground cable lines using the pavement surface radiation properties. Iet Generation Transmission \& Distribution. 2018;10:2968 2976.

11. Matthew, J., W., Cock, Joop, C., et al. Biological control agents: safety and regulatory policy. Biocontrol. 2003;48:477-484.

12. Kraaijeveld D. Biological control aphid. Vida Rural. 2006.

13. Pons X, Lumbierres B, Antoni R, Starý P. Parasitoid complex of alfalfa aphids in an IPM intensive crop system in northern Catalonia. Journal of Pest ence. 2011;84(4):437-45. 
14. Sigsgaard L. A survey of aphids and aphid parasitoids in cereal fields in Denmark, and the parasitoids' role in biological control. Journal of Applied Entomology. 2010;126:101-107.

15. Yang F, Wu YK, Xu L, Wang Q, Yao ZW, ?iki? V, et al. Species composition and richness of aphid parasitoid wasps in cotton fields in northern China. entific Reports. 2017;7(1):97-99.

16. Alichi M, Shishehbor P, Mossadegh MS, Nejadian ES. Species Composition and Distribution of Wheat Aphids and Their Parasitoids in Shiraz Region, and Seasonal Dynamics of the Dominant Species. Journal of Science \& Technology of Agriculture \& Natural Resources. 2008;45:287-295.

17. Archer TL, Cate RH, Eikenbary RD, Starks KJ. Parasitoids Collected from Greenbugs1 and Corn Leaf Aphids1 in Oklahoma in 1972. Annals of the Entomological Society of America.1972;1:20-24.

18. Baoyu Han; Zhongning Zhang. Spatial-temporal pattern and diversity and stability of orthoptera communities in Masson pine forest. Acta Entomologica Sinica 2000.

19. Yunding, Z.; Chengcheng, D.; Shoudong, B.; Caiqiu, G.; Chuanwang, C.; Xiaolin, L.; Qinglei, M.; Changgen, L. Cluster analysis on the temporal dynamics of arthropod community in a plum orchard. The journal of applied ecology .2005;16(4):631.

20. Zhang Yanling; Bi Shoudong; Zou Yunding; Li Baoqiang. Research on the dynamics of arthropod community structure in Linmai No. 4 wheat field. Anhui Agricultural Science Bulletin 2009;15:147-147.

21. Shiyomi M, Nakamura K. Experimental studies on the distribution of the aphid counts. Researches on Population Ecology. 1964;6(2):79-87.

22. Zhang Dapeng. Research on the occurrence of corn aphids in Harbin area[D]. Heilongjiang University . 2012.

23. Yang Jie. Research on population dynamics of main crop pests and predatory natural enemies in Jilin Province[D]. Jilin Agricultural University .2013.

24. Yan Zhanfeng. Study on the relationship between the occurrence of aphids and their natural enemies in corn fields. Chinese Academy of Agricultural Sciences.2011;6:4-10.

25. Li Hepeng; Shan Dapeng; Shao Shanshan; Yang Guangyi; Shen Haijun. The occurrence of aphids in corn fields in Suihua area. Heilongjiang Agricultural Sciences.2018;285: 49-51. 
26. Pons JM. Feeding strategies of male and female Herring gulls during the breeding season under various feeding conditions. Monitore Zoologico Italiano Italian Journal of Zoology. 1994;6(1):1-12.

27. Chia-Yu, Chen, Chi-Yung, LaiMei-Hwa, Kuo. Temperature effect on the growth of Buchnera endosymbiont in Aphis craccivora (Hemiptera: Aphididae). Symbiosis. 2009;67:156-158.

28. Rusk R, Sievers JL. Management of Corn Aphids. Iowa State University. 2010;30:34-36.

29. Hodgson EW, Vannostrand GR, Rusk R. Aphids in Corn Research. 2012;6:70-72

30. Sahaza JH, Pérez-Torres A, Zenteno E, Taylor ML. Usefulness of the murine model to study the immune response against Histoplasma capsulatum infection. Comparative Immunology Microbiology \& Infectious Diseases. 2014;37(3):143-52.

31. Luis A, Xavier P. Effect of High Temperature on the Growth and Reproduction of Corn Aphids (Homoptera: Aphididae) and Implications for Their Population Dynamics on the Northeastern Iberian Peninsula. Environmental Entomology. 2001; 6:1127-1134.

32. Starý DP, Lyon JP, Leclant F. Biocontrol of aphids by the introduced Lysiphlebus testaceipes (Cress.) (Hym., Aphidiidae) in Mediterranean France. Journal of Applied Entomology. 1988;12:132-135.

33. Hopkinson J. Host plant, Aphis gossypii Glover (Hemiptera: Aphididae) and Lysiphlebus testaceipes (Cresson) (Hymenoptera: Braconidae) interactions: potential for aphid biological control in cotton cropping systems. Cotton. 2010;130:325-326.

34. Gagic V, Hnke S, Thies C, Scherber C, Tomanovi e, Tscharntke T. Agricultural intensification and cereal aphid-parasitoid-hyperparasitoid food webs: network complexity, temporal variability and parasitism rates. Oecologia. 2012;170(4):1099-1109. 